\title{
The use of size and growing height to improve Crassostrea gigas farming and breeding techniques against OsHV-1
}

\author{
Azéma Patrick ${ }^{1}$, Maurouard Elise ${ }^{1}$, Lamy Jean-Baptiste ${ }^{1}$, Dégremont Lionel ${ }^{1,{ }^{*}}$ \\ ${ }^{1}$ IFREMER, RBE-SG2M-LGPMM, Station de La Tremblade, Avenue de Mus de Loup, F-17390 La \\ Tremblade \\ * Corresponding author : Lionel Dégremont, email address : lionel.degremont@ifremer.fr
}

\begin{abstract}
:
Mortality associated with ostreid herpesvirus 1 (OsHV-1) has significantly impacted Crassostrea gigas farmers all around the world. Although selective breeding programs to improve OsHV-1 resistance can significantly reduce the mortality rate below $20 \%$, husbandry practices have also been one way to limit or decrease mortality. The main objectives of this study were to describe the influence of two husbandry practices on OsHV-1-induced mortality in C. gigas spat and how different family lines respond to husbandry practices to gain a better understanding of the potential benefits of breeding management as a tool to adapt to improved practices. The first analysis investigated the importance of the size of $C$. gigas when challenged with OsHV-1 for the first time. For each of the 40 families of $C$. gigas evaluated, small (S) and large (L) oyster groups were tested for two years in the field. A significant mortality outbreak associated with OsHV-1 occurred during the first spring. At the end of the trial, the mean cumulative mortality of the $L$ group $(54.1 \%)$ was significantly lower than the mean cumulative mortality of the S group (74.8\%), indicating the importance of size in OsHV-1-associated mortality. However, the overall effect of size was not consistent for all families: in 11 of the 40 families tested, there appeared to be no difference in mortality between the $S$ and $L$ groups. Observations at the family level allowed the identification of a large range of susceptibility to OsHV-1 regardless of the size group, with highly resistant families $(<32 \%)$ and highly susceptible families $(>80 \%)$. The second investigation compared different growing heights. Each of the 40 families was grown at three heights (high $\mathrm{Hi}$, medium Me, and low Lo) corresponding to mean emersion times of 25, 12 and $2 \%$, respectively. After an OsHV-1-related mortality outbreak, the mean mortality among the families was $91.6 \%, 88.0 \%$ and $86.9 \%$ for the Lo, Me and $\mathrm{Hi}$ conditions, respectively. Growing height had no effect in 31 of the 40 families tested, and these families showed no potential for adaptation to improve growing height practices. Among them, 24 families showed extremely high mortality (>95\%) and 2 families showed the lowest mortality $(<40 \%)$. In contrast, nine families showed differences in mortality associated with growing heights. A tendency toward higher mortality was observed for oysters that emerged less, with $85 \%$ for Lo compared to $72 \%$ for $\mathrm{Hi}$. A protective effect of a high growing height on spat oysters was confirmed. In both experiments, higher relative growth rates were associated with higher mortality by OsHV-1. Finally, we identified oyster families from the two husbandry practices that were resistant or susceptible to OsHV-1 infection regardless of their size, growing height and age. Finally, a moderate heritability of mortality, ranging from 0.44 to 0.49 , was determined from the size investigation.
\end{abstract}


Statement of relevance

Husbandry practices can decrease OsHV-1 mortality in C gigas, but it depends on the genetic resistance of the oyster stocks used.

\section{Highlights}

Larger oysters had lower mortality than smaller ones when exposed to OsHV-1 for most of the 40 families tested. Lower mortality for high growing heights but only for families which are not highly resistant or highly susceptible to OsHV-1. Higher growth is associated to higher susceptibility to OsHV-1. Moderate heritability for OsHV-1-associated mortality ranging from 0.44 to 0.49

Keywords : Mortality, Crassostrea gigas, Size, OsHV-1, Growing height 


\section{Introduction}

The ostreid herpesvirus 1 OsHV-1 causes severe mortality outbreaks in Crassostrea gigas in many countries where $C$. gigas is cultivated, including in Europe (Domeneghetti et al., 2014; Lynch et al., 2012; Peeler et al., 2012; Roque et al., 2012), the USA (Burge et al., 2006), New Zealand (Keeling et al., 2014), and Australia (Jenkins et al., 2013; Paul-Pont et al., 2014). A new pattern of mass mortality in C. gigas has been observed in European countries since 2008 (EFSA, 2015). This finding is particularly evident in France, where massive mortality events in young $C$. gigas have become more regular and widespread. These have been ascribed to a particular genotype of the ostreid herpesvirus 1, OsHV-1, called $\mu$ Var (Segarra et al., 2010). Although herpes-like virus was detected in C. gigas larvae as early as 1991 (Nicolas et al., 1992) and regularly between 1998 and 2002 (Garcia et al., 2011), the exact cause of the increased mortality remains unknown. Moreover, significant mortality associated with the detection of Vibrio aestuarianus has been observed in market-sized adults since 2012 (Azema et al., 2015c).

C. gigas is susceptible to OsHV-1 in all stages of development, including larvae (Dégremont et al., 2016; Le Deuff et al., 1994), spat (Garcia et al., 2011; Pernet et al., 2012), juveniles (Azema et al., 2015c; Dégremont, 2013), and adults (Dégremont et al., 2013; Whittington et al., 2015). For the latter, it has been argued that mortality is significantly reduced in adults compared with the other age groups (Peeler et al., 2012). This result is partially explained by genetic resistance in the oysters that survive beyond the spat stage (Dégremont et al., 2010). Nevertheless, higher mortality rates are observed in younger individuals compared to adult oysters when using unselected naïve oysters (Paul-Pont et al., 2013a). This statement highlights the importance of the age and/or size of the oysters when challenged with OsHV-1 
for the first time (Paul-Pont et al., 2014; Pernet et al., 2012; Petton et al., 2015).

To understand the role played by age and size on susceptibility to OsHV1, three groups of naïve oysters were analyzed (control and selected for either resistance or susceptibility to OsHV-1) at ages varying from 3 to 20 months and sizes varying from 1 to $25 \mathrm{~g}$ (Dégremont, 2013). Both age and size were negatively correlated with the final cumulative mortality, but the relationship between mortality and size $(r=-0.87)$ was stronger than the relationship between mortality and age $(\mathrm{r}=-0.55)$ (Dégremont, 2013). This finding was in agreement with a higher resistance of larger oysters to OsHV-1 at the time of the mortality event (Burge et al., 2007).

Recently, the hypothesis that links resistance to OsHV-1 infection and oyster size has been questioned by two studies. The first observed that the shell lengths of live and dead oysters were similar after an OsHV-1 outbreak, suggesting that there was no relationship between disease susceptibility and oyster size (Petton et al., 2015). The second study reported that age was found to be a significant determinant of mortality rate after allowing for variation in mortality due to size, but size was not significant after allowing for variation in age (PaulPont et al., 2014).

Nevertheless, phenotypic variance for OsHV-1 resistance is driven by a high and significant genetic variance (Dégremont et al., 2015b). Thus, genetic variation may impact the phenotypic responses, and a low sample size in terms of genetic background could blur the relationship between age/size and OsHV1 resistance. Though a preliminary experiment testing three groups of oysters at different ages and the same size has been done (Dégremont, 2013), a better way to obtain additional insights would be to produce different germplasms and test them at the same age but at different sizes. This study used this genetic approach by testing two sizes from 40 bi-parental families at the same age. 
In addition, a second experiment was performed to compare growing height among the same families. High growing height was recently identified to have a protective effect on adult oysters, which exhibited a lower cumulative mortality than those with a low growing height (Paul-Pont et al., 2013a; Whittington et al., 2015). Oyster farmers would be interested in these husbandry practices if they significantly limit OsHV-1-associated mortality.

The primary objective of this study was to stress genetic effects on the outcomes of husbandry practices on OsHV-1-induced mortality in $C$. gigas by testing 40 full-sib families. Our study aimed to provide valid practical solutions to limit or decrease the OsHV-1-induced mortality. It also contributed to the identification of resistant and susceptible families for OsHV-1associated mortality, as well as a more accurate estimation of OsHV-1 resistance.

2. Materials and methods

\subsection{Biological materials}

In December 2012, wild C. gigas oysters were sampled on an oyster bed located in the estuary of the Seudre River (Marennes-Oleron Bay - 4546'53.5" N, $1^{\circ} 7^{\prime} 19.5^{\prime \prime} \mathrm{W}$ ). It is likely that wild broodstock contained some individuals that were survivors of mortality related to OsHV1. Nevertheless, oysters produced from mass spawns using wild oysters between 2008 and 2016 still exhibited high susceptibility to OsHV-1. The oysters were brought to the Ifremer facilities in La Tremblade and placed in 240-L conditioning tanks with a flow of $400 \mathrm{~L} \mathrm{~h}^{-1}$. Seawater temperature was gradually increased to $21{ }^{\circ} \mathrm{C}$ for one week and enriched with a cultured phytoplankton diet ad libitum (Isochrysis galbana, Tetraselmis suecica and Skeletonema costatum) to favor gametogenesis. The oysters were maintained in these 
conditions until reproduction. In March 2013, the oysters were opened and sexed by microscopic observation of gonad samples spread on a slide. Only mature oysters were kept for mating, and the oysters were separated by sex. The gametes were individually collected by stripping the gonad from 20 males and 40 females. Eggs were sieved through a $60-\mu \mathrm{m}$ mesh and retained on a $20-\mu \mathrm{m}$ mesh screen to remove tissue debris. The sperm were sieved through a $60-\mu \mathrm{m}$ mesh screen.

Fertilization was performed using a nested half-sib breeding scheme (called North Carolina I); each male was mated with 2 females, producing 20 half-sib families (HSF) that each contained 2 full-sib families (FSF). The $40 \mathrm{FSF}$ were reared separately in 30 -L tanks at $25^{\circ} \mathrm{C}$ using UV-treated, filtered seawater $(5 \mu \mathrm{m})$. The water was changed 3 times a week. Larvae were fed daily with I. galbana $(30,000$ cells $/ \mathrm{mL})$ until they reached $140 \mu \mathrm{m}$, and then the phytoplankton diet was supplemented with $S$. costatum $(30,000$ cells $/ \mathrm{mL})$.

Fourteen to 18 days after fertilization, the larvae from all families settled on cultch in $120-\mathrm{L}$ raceways with UV-treated seawater heated to $21^{\circ} \mathrm{C}$. The size of the cultch $(200-300 \mu \mathrm{m})$ was chosen so that one larva would settle per piece of cultch to produce a single spat. The seawater flow was $300 \mathrm{~L} \mathrm{~h}^{-1}$ and was enriched with S. costatum. The families were always reared separately under standard hatchery conditions until they reached 2-mm size. Then, each family was grown in two sites, with 5,000 oysters per family transferred to the Ifremer nursery in Bouin (Vendée, France) in May 2013 and 2,000 oysters per family maintained in the hatchery facilities in La Tremblade. During these production steps, no mortality was recorded.

2.2. Experimental design for the size investigation 
In May 2013, each family that was maintained at the Ifremer hatchery in La Tremblade was separated into two groups, one with 500 oysters and the other with 1,500 oysters. In all families, each group was maintained in a separate tank with flow-through and UV-treated seawater enriched with S. costatum. To obtain two size groups per family with the same genetic characteristics, the only parameter distinguishing the two groups was the density. This protocol was chosen to prevent eventual effects of positive or negative genetic correlations between growth and mortality when subsequently selecting the largest and the smallest oysters from a unique group. In November 2013, 100 oysters per family were randomly sampled within the group of 500 oysters to produce the large size group (L) for each family. The total weight of the oysters was recorded, and they were placed in a bag. Similarly, 100 oysters per family were sampled within the group of 1,500 oysters to produce the small size group (S). The mean individual weight among families was $0.43 \mathrm{~g}$ (SD 0.21) and $4.73 \mathrm{~g}$ (SD 1.65) for the $\mathrm{S}$ and $\mathrm{L}$ groups, respectively. Eighty bags from 40 families, each with $\mathrm{L}$ and $\mathrm{S}$ groups, were deployed in our oyster farms at Agnas in the Marennes-Oléron Bay $\left(45^{\circ} 52^{\prime} 23^{\prime} \mathrm{N}, 1^{\circ} 10^{\prime} 15^{\prime} \mathrm{W}\right)$ on November $26^{\text {th }}, 2013$. In 2011 , the ranking of 46 families for their susceptibility to OsHV-1 was similar among several culture methods (e.g., different densities or mixed or separated families), suggesting a similar probability for OsHV-1 infection in this site (Dégremont et al., 2015b). We assumed each of the 40 families tested in our study, regardless their size group, had the same probability of exposure to OsHV-1. The bags were randomly attached to racks. The site is characterized by a mixture of sand and mud, and it is surrounded by numerous oyster leases. Emersion time at the site was $12 \%$.

Every month, the oyster bags were checked, but mortality was not estimated until its onset. Then, mortality was recorded by counting the numbers of dead and live oysters in June, July, September and November 2014, as well as in May and October 2015. During counting, samples were taken from all moribund oysters in all families, with the exception of the peak 
mortality when only 30-31 oysters were sampled per size group. No moribund oysters were sampled from November 2014 to October 2015 due to the absence of a significant mortality event. The total weights of the live oysters were recorded in November 2014, May 2015 and October 2015. Finally, shell length and individual weight of the shells of 30 dead oysters were measured in June 2014 to confirm the difference in size between the L and S groups at 7 months post-seeding. This number was lower for families with low mortality. The seawater temperature was recorded every hour throughout the study using two ThermoTrack probes (Progesplus, 59780, Willems, France).

2.3. Experimental design for the growing height investigation

On July $26^{\text {th }}, 2013$, oysters raised at the Ifremer nursery in Bouin were three months old, and the average individual weight among all families was $2.29 \mathrm{~g}$ (SD 0.59). Average shell lengths of the families were not recorded but were estimated to be $28 \mathrm{~mm}$ according to our length/weight database for $C$. gigas. All families were seeded at Agnas, the same site as described above, at three growing heights: high (Hi), medium (Me) and low (Lo). The Hi, Me and Lo growing heights corresponded to mean emersion times of $25 \%, 12 \%$ and $2 \%$, respectively. Four bags containing each of the 40 families with 25 spat per family were used at each growing height. Within each bag, the families were separated using soft mesh bags with a label indicating the family name. All bags were fixed on racks. In 2011, the ranking of 46 families for their susceptibility to OsHV-1 was similar among several culture methods (e.g., different densities or mixed or separated families), suggesting a similar probability for all of them to be infected by OsHV-1 in this site (Dégremont et al., 2015b). We assumed each of the families within each of the bags had the same probability of exposure to OsHV-1. Mortality was checked two weeks post-deployment and recorded 6 weeks post-deployment on 
September $6^{\text {th }}, 2013$. Twelve moribund oysters were sampled two weeks post-deployment, but only at the Me condition. Seawater temperature was recorded every hour using two ThermoTrack probes (Progesplus, 59780, Willems, France).

\subsection{Detection of OsHV-1 and Vibrio aestuarianus DNA}

Moribund oysters collected in both experiments were individually analyzed to detect the two main pathogens involved in C. gigas mortality in France since 2008: OsHV-1 and Vibrio aestuarianus. Total DNA was extracted from tissue fragments (mantle + gills) using the QIAgen (Hilden, Germany) QIAamp tissue mini kit and the automated QIAcube according to the manufacturer's protocol, as described in Schikorski et al. (2011). The total DNA concentration was measured on a Nanodrop spectrophotometer (Thermo Scientific) and adjusted to $5 \mathrm{ng} / \mu 1$.

The OsHV-1 DNA was detected and quantified with the $\mathrm{SYBR}^{\circledR}$ green real-time PCR protocol described by Pépin et al. (2008) and adapted for use with DPFor/DPRev primers to target the OsHV-1 DNA polymerase sequence (ORF 100; DPF 5' ATT GAT GATGTG GAT AAT CTG TG 3' and DPR 5' GGT AAA TAC CAT TGG TCT TGTTCC 3'; (Pepin, 2013). The $V$. aestuarianus DNA was detected and quantified by real-time PCR according to the protocol described in Saulnier et al. (2009); DNAj-F 5, GTATGAAATTTTAACTGACCCACAA3'; DNAj-R 5' CAATTTCTTTCGAACAACCAC 3'; and DNAj probe 5' TGGTAGCGCAGACTTCGGCGAC). The real-time PCR cycling conditions were as follows: $3 \mathrm{~min}$ at $95^{\circ} \mathrm{C}$, followed by 40 cycles of amplification at $95^{\circ} \mathrm{C}$ for $5 \mathrm{~s}$ and $60^{\circ} \mathrm{C}$ for $20 \mathrm{~s}$. Negative controls (without DNA) were included. The results were expressed as viral or bacterial DNA copy number per mg of oyster tissue. 


\subsection{Data analyses}

\subsubsection{Size investigations}

All statistical analyses were conducted using SAS $^{\circledR} 9.4$ software.

To assess if the size of each individual has an impact on the rate of mortality events, we set up a randomized complete block design. Each family was considered as a block and size as the factor. Each individual is the smallest statistical unit that determines the total number of degrees of freedom.

The impact of size on mortality related to OsHV-1 was analyzed in November 2014 and in October 2015 with a binomial logistic regression equation using the GLIMMIX procedure and the following model:

$\operatorname{Logit}\left(Y_{i j k}\right)=\mu+G_{j}+F_{i}+G_{j} x F_{i}$

where $\mathrm{Y}_{\mathrm{ijk}}$ is the probability that the $\mathrm{k}$ th oyster from the $j$ th group (L or S) of the $i$ th family (1 to 40) will die, and $\mu$ is the intercept; $G_{\mathrm{j}}$ is the size factor and declared as a fixed effect and $F_{\mathrm{i}}$ is a block effect (family). $F_{\mathrm{i}}$ and $G_{j} \times F_{i}$ are both random effects and their significance was determined by the likelihood ratio statistic, computed by calculating the difference between the -2 log-likelihood for the full model and for the reduced model.

For each family and at each size class (L and S), the individual weight was estimated as the total weight of live oysters divided by the number of live oysters. The difference in the mean individual weights (only one value per family) between the two size groups, L and S, was analyzed at seeding in November 2013 and in November 2014, June 2015 and October 2015 
using the GLM procedure.

Daily specific growth (SGR) was calculated for each family according to the formula:

$\mathrm{SGR}=\left(\ln \mathrm{Wt}_{1}-\ln \mathrm{Wt}_{0}\right) /\left(\mathrm{t}_{1}-\mathrm{t}_{0}\right)$

where $\mathrm{Wt}_{1}$ is the individual weight in November 2014 , and $\mathrm{Wt}_{0}$ is the individual weight in November 2015 and $t_{1}-t_{0}$ is the duration of the experiment between the two dates in days. The same calculation was done between November 2014 and June 2015, and between June 2015 and October 2015. SGR was then analyzed using the GLM procedure to test the size group effect.

Lengths and weights of the shells from dead oysters measured in June 2014 were analyzed using the GLM procedure by comparing the two size groups from each family.

\subsubsection{Growing height investigation}

To assess if the growing height of each individual has an impact on the rate of mortality events, we set up a split-plot experiment with a randomized complete block design. Growing height was considered as a whole plot factor, family as a subplot factor, and bags as a block effect. Each individual is the smallest statistical unit determining the total number of degrees of freedom.

Mortality was analyzed in September 2013 using the same procedure described above and the following model:

$\operatorname{Logit}\left(\mathrm{Y}_{\mathrm{ijkl}}\right)=\mu+G_{\mathrm{i}}+F_{\mathrm{j}}+B_{\mathrm{k}}\left(G_{\mathrm{i}}\right)+G_{\mathrm{i}} \times F_{\mathrm{j}}$

where $\mathrm{Y}_{\mathrm{ijkl}}$ is the probability that the $l$ th oyster of the $j$ th family (1 to 40) at the $i$ th growing 
height (Lo, Me and Hi) in the $k$ th bag will die; and $\mu$ is the intercept, $G i$ is the growing height factor, and $F_{j}$ is family factor and $B_{\mathrm{k}}$ is a block effect (bag) nested within the growing height factor. Only the growing height was declared as fixed effect, the others were random. The bag effect was removed from the model because it was not significant.

Individual weights for each of the four replicates at the three growing heights was estimated as the total weight of live oysters divided by the number of live oysters. The difference in the mean individual weights between the three growing heights was analyzed on September $6^{\text {th }}$, 2013, using the GLM procedure with the individual weight at seeding as the covariable.

\subsubsection{Genetic parameters}

Cross sectional models are simple statistical procedures that can be defined to analyze disease resistance measured as a single record (e.g., alive/dead) at a fixed point in time (Ødegård et al., 2011). Hence, the time of death is not taken into account.

For the size study (L and S groups), the mortality was approximately $50 \%$, a value at which variances in the binary trait are maximized, given the best estimation of heritability (Ødegård et al., 2011). The data were analyzed with a generalized linear mixed model (GLMM) using the SAS GLIMMIX procedure with a logit link and the Laplace method to approximate the log likelihood (SAS, 2014). Males and females nested within males were the random factors, and the mean weight of the individual was considered as a fixed effect. Dominance was assumed to be negligible for separate estimation of the other causal components of variance. The GLMM estimators were provided in the underlying liability scale and the genetic parameters were directly computed. The SAS codes used are shown in the supplementary material in Dégremont et al. (2015b). 
Narrow $\left(h^{2} n\right)$, broad $\left(h^{2} b\right)$ and combined heritabilities $\left(h^{2} m+f\right)$ for mortality were computed as follows (Falconer, Mackay, 1996):

$\mathrm{h}^{2} \mathrm{n}=\mathrm{Va} / \mathrm{Vt}=4 \sigma^{2} \mathrm{~m} /\left(\sigma^{2} \mathrm{~m}+\sigma^{2} \mathrm{f}+\sigma^{2} \mathrm{e}\right)$

$h^{2} b=V g / V t=4 \sigma^{2} f /\left(\sigma^{2} m+\sigma^{2} f+\sigma^{2} e\right)$

$h^{2} \mathrm{~m}+\mathrm{f}=2 \times\left(\sigma^{2} \mathrm{~m}+\sigma^{2} \mathrm{f}\right) / \mathrm{Vt}$

where $\mathrm{Va}$ and $\mathrm{Vg}$ are the additive genetic variance and genetic variance, respectively, which were estimated as four times the variance among males $\left(\sigma^{2} \mathrm{~m}\right)$ and four times the variances among females $\left(\sigma^{2} \mathrm{f}\right), \mathrm{Vt}$ is the total phenotypic variance, and $\sigma^{2} \mathrm{e}$ is $\pi^{2} / 3$ for a logit link (Ødegård et al., 2007).

For the growing height investigations, the extreme mortality rate (mean $88.8 \%$, median $97.0 \%$ ) combined with a relatively low number of families (40) jeopardized the estimation of variance, and consequently, heritability was not calculated (Ødegård et al., 2011).

3. Results

\subsection{Size investigation}

\subsubsection{Seawater temperature}

In France, OsHV-1 becomes virulent at and above $16^{\circ}$ C. From November 2013 to October 2015, the seawater temperature at Agnas ranged from $4.7^{\circ} \mathrm{C}$ in February 2015 to $22.6^{\circ} \mathrm{C}$ in July 2014, as shown in Fig. 1. At deployment, the seawater temperature was below $10^{\circ} \mathrm{C}$, and it reached $16^{\circ} \mathrm{C}$ temporarily on May $9^{\text {th }}$ and May $16^{\text {th }}$. The seawater temperature stayed above $16^{\circ} \mathrm{C}$ from May $27^{\text {th }}, 2014$ to November $11^{\text {th }}, 2014$ and from May $24^{\text {th }}, 2015$ to 
October $10^{\text {th }}, 2015$.

\subsubsection{Mortality}

No mortality was reported from November 2013 to April 2014. Some moribund oysters were observed on May $15^{\text {th }}$. A significant mortality outbreak was then observed on May $28^{\text {th }}$, and mortality reached $31.7 \%$ and $64.5 \%$ for the L and S groups, respectively, on June $12^{\text {th }}, 2014$ (Fig. 1). At the end of the first growing season in November 2014, the mean cumulated mortality among families reached $54.1 \%$ and $74.8 \%$ for the $\mathrm{L}$ and $\mathrm{S}$ groups, respectively. Mortality was lower than 1\% during overwintering for both groups, and in October 2015 the final cumulative mortality was $58.6 \%$ and $76.7 \%$ for the $\mathrm{L}$ and $\mathrm{S}$ groups, respectively.

A significant interaction between family and size group was observed in November $2014(P<$ 0.0001; Table 1), which is illustrated in Fig. 2. The mortality was significantly higher for the S group than the L group for 29 families $(P<0.05)$, whereas both the $\mathrm{L}$ and $\mathrm{S}$ groups from 11 families exhibited similar mortalities. Among those 11 families, 4 displayed low mortality $(<32 \%)$ and 4 displayed high mortality $(>80 \%)$, regardless of size. The same findings were observed in October 2015.

\subsubsection{Size and growth}

At deployment in November 2013, the mean individual weight of the L group (4.73 g) was significantly higher than the $\mathrm{S}$ group $(0.43 \mathrm{~g} ; P<0.0001)$. This trend was consistent in November 2014, May 2015 and October 2015 (Fig. 3). At the end of the trial, the mean individual weight among the families was significantly higher in the L group (79.95 g) than in the $\mathrm{S}$ group (59.95 g; $P<0.0001)$.

SGR was highest between November 2013 and November 2014, with 0.012 and 0.006 g.d $\mathrm{d}^{-1}$ 
on the ln scale for the S and L groups, respectively, and then decreased to 0.002 for both groups between November 2014 and May 2015 and between May 2015 and October 2015 (Fig. 3). There was a significant difference of SGR between the two groups only for the first period with a better growth for the $\mathrm{S}$ group $(P<0.0001)$.

During the peak of mortality, the mean shell lengths and weights of the dead oysters were $42.95 \mathrm{~mm}$ and $6.95 \mathrm{~g}$ for the $\mathrm{L}$ group and $34.87 \mathrm{~mm}$ and $1.93 \mathrm{~g}$ for the $\mathrm{S}$ group, respectively. For each family, the lengths and weights of the shells from the $L$ group were always significantly higher than those of the $\mathrm{S}$ group $(0.0001<P<0.0094$; Fig. 4).

\subsubsection{OsHV-1 and V. aestuarianus detection}

For both the L and S groups, all moribund oysters sampled from May 2014 to September 2014 were positive for OsHV-1, with a high amount of viral DNA $\left(>10^{6}\right.$ copies per mg of fresh oyster tissue; Table 2). In contrast, V. aestuarianus was not detected in the L group in May 2014 during the main peak of mortality, whereas it was detected in $13 \%$ of the S group individuals. In June, July and September 2014, V. aestuarianus was detected in both groups, ranging from 20 to $44 \%$ in June and September, whereas it was detected in 71 and $100 \%$ of the L and S groups, respectively, in July. The amount of bacterial DNA was the lowest in June $\left(10^{+4}\right.$ copies per $\mathrm{mg}$ of fresh oyster tissue $)$ and the highest in July $\left(10^{+7}\right.$ copies per $\mathrm{mg}$ of fresh oyster tissue; Table 2).

3.2. Growing height investigation

3.2.1. Seawater temperature 
Seawater temperature averaged $20.6^{\circ} \mathrm{C}$ and ranged from $19.1^{\circ} \mathrm{C}$ to $22.3^{\circ} \mathrm{C}$ during the six weeks of this trial.

\subsubsection{Mortality}

Fifteen days after seeding, a massive mortality outbreak was observed, with many moribund oysters at the Hi, Me and Lo growing heights. At the end of the trial on September $6^{\text {th }}, 2013$, the mean mortality among the 40 families was $91.6 \%, 88.0 \%$ and $86.9 \%$ for the Lo, Me and Hi conditions, respectively (Fig. 5). A significant interaction between family and growing height was observed $(P<0.0001 ;$ Table 3$)$. At the family level, mortality was not significantly different among the growing conditions for 31 families, which were mostly the families that displayed extremely high mortality ( 24 families had mortality rates $>95 \%$ ) or families showing the lowest mortality ( 2 families had mortality rates $<40 \%$ ), regardless of growing height conditions. In contrast, significant differences in mortality among the growing conditions were observed for 9 families, with a tendency toward higher mortality for the Lo condition (85\%) and lower mortality for Hi condition (72\%; Fig. 6).

\subsubsection{Growth}

At seeding on July $26^{\text {th }}, 2013$, the mean individual weights of the oysters were $2.24,2.28$ and $2.35 \mathrm{~g}$ for Lo, Me and Hi groups, respectively. At the end of the trial on September $6^{\text {th }}, 2013$, the mean individual weight of the oysters was significantly different among the growing height conditions $(P<0.0001)$, with the lowest weight for Hi $(4.88 \mathrm{~g})$, intermediate weight for Me $(6.30 \mathrm{~g})$ and the highest weight for Lo $(7.62 \mathrm{~g})$. 


\subsubsection{OsHV-1 and V. aestuarianus detection}

All oysters examined were positive for high concentrations of OsHV-1 DNA $\left(>10^{6}\right.$ copies of OsHV-1 DNA per mg of fresh oyster tissue), but none were positive for $V$. aestuarianus.

\subsection{Genetic parameters for mortality}

The variance components and heritabilities for the size investigation are presented in Table 4 . Narrow-sense heritabilities were high for the L group $(0.47 \pm 0.22)$ and the $\mathrm{S}$ group $(0.62 \pm$ $0.32)$ in November 2014, as well as for both groups combined $(0.45 \pm 0.23)$. Similar values were obtained for broad sense and combined heritabilities in November 2014 and October 2015. 
4. Discussion

The main objectives of this study were to further describe observations of the influence of husbandry practices on OsHV-1-induced mortality in $C$. gigas by testing 40 full-sib families. The use of 40 families subjected to various conditions to control the size of individuals and the growing height, instead of using one single group of oysters, allowed us to gain a better understanding of the complexity of mortality in field conditions. The two experiments also assessed the differences between genetically distinct batches of oysters, which could be used in future breeding to address OsHV-1 susceptibility.

\subsection{Mortality and OsHV-1/V. aestuarianus}

Two seedings were conducted in our study. The first was in July 2013 for the growing height investigation, and a massive mortality event occurred two weeks post-seeding and lasted for two weeks. The second seeding occurred in November 2013 for the size investigation, and the onset of the mortality outbreak occurred in May 2014 when the seawater temperature was approximately $16^{\circ} \mathrm{C}$ and lasted for one month (Fig. 1). Such observations are common for OsHV-1-associated mortality under field conditions in France when the seawater temperature exceeds (as in the growing height investigation) or reaches $16^{\circ} \mathrm{C}$ (as in the size investigation), as has been reported between 2009-2011 in Thau (Pernet et al., 2012), since 2009 in the Marennes-Oléron Bay (Dégremont, 2013; Dégremont et al., 2015a), or in 2011 in Brittany (Petton et al., 2015). The detection of a large amount of OsHV-1 DNA ( $>10^{6}$ copies per mg of fresh oyster tissue) for all moribund oysters strongly supports that OsHV-1 was one of the main causes of mortality (Table 2). Although V. aestuarianus was also detected during the 
size investigations (Table 2), its role was quite limited during the peak of the mortality in May 2014, as only 4 of 61 oysters were positive. Meanwhile, both pathogens, particularly OsHV1, were detected in moribund oysters from June to September 2014, and both may have roles in the mortality observed during this period (Table 2). Usually, the detection frequency and quantity of OsHV-1 DNA decreases markedly after an OsHV-1-related mortality outbreak in live oysters (Dégremont, 2011; Paul-Pont et al., 2013a; Pernet et al., 2012). Nevertheless, in our study, even after a major OsHV-1-related mortality outbreak, some oysters still died. The detection of a high level of $V$. aestuarianus DNA in some oysters suggests the presence of a dual infection similar to that recently described by Azéma et al. (2016). Both pathogens could then interact and kill the oysters that survived the primary infection with OsHV-1. To our knowledge, this finding has not been reported in the literature, and requires further investigation.

\subsection{Size investigation}

Our study tested oysters of different sizes at the same age, which were 15 months old at the onset of the mortality outbreak. It was clear that oyster size is a significant factor to explain the intensity of mortality associated with OsHV-1 infections, which is in agreement with the studies by Burge et al. (2007) and Dégremont (2013). Most of the families had lower virusassociated mortality when oysters were larger (Fig. 2), indicating that large oysters are more resistant to OsHV-1 infection than small oysters at 15 months of age. This finding was also observed in C. gigas seed at Inner Tomales Bay in 2001, for which OsHV-1 was suspected as a possible cause of mortality (Burge et al., 2007). For this reason, oysters were seeded either in the autumn or the following spring, and the autumn cohorts outperformed those planted in the spring because they were a much larger size at the time of the mortality event (Burge et 
al., 2007). The protocol used in Burge et al. (2007) and our protocol generated the two size groups similarly by varying the environmental conditions (growing sites and density, respectively), but neither protocol created two size groups by selecting the largest and the smallest oysters within a single group. This last approach remains to be investigated, but it could have a major disadvantage in understanding the root cause of resistance due to a possible genetic correlation between mortality and growth.

Our results contrasted with other studies that did not observe a significant impact of size on OsHV-1-associated mortality. However, their conclusions were based on i) a small size range of oysters, ranging from 2 to $>7 \mathrm{~mm}$ (Clegg et al., 2014); ii) a reduced sample size and narrow genetic background (6 transfers for one stock produced from 10 males and 20 females but without data on the mating design); and iii) the comparison of the shell lengths between live and dead oysters from a limited number of oyster stocks after the outbreak, without a true comparison of the mortality rates between two size groups within each stock (Petton et al., 2015).

A preliminary hypothesis to explain the higher susceptibility to OsHV-1 of the S group is that manipulation of oyster size by adjusting the density may have resulted in nutritional stress in the small-sized group due to a reduced food ration. Our design was chosen to avoid possible genetic correlation between growth and resistance to OsHV-1, which would have been present if the largest and the smallest specimens from a unique stock were chosen. Moreover, it is likely that the smallest spat from a unique stock would also be under nutritional stress too. Although our experimental design tried to minimize potential nutritional stress by planting the oysters in the field 7 months before the onset of the OsHV-1-associated mortality, this stress could have increased the susceptibility of the oysters for the S group to virus infection. However, a recent study investigated the starvation effect on susceptibility to OsHV-1 for a 
resistant and a susceptible family, the same as used in our study. The preliminary results showed that starvation decreased susceptibility to OsHV-1, which could be explained if OsHV-1 could not rely on host cell replication machinery.

We also posit the hypothesis that S oysters had a higher growth rate than the L oysters, which was twice as fast during the first year of the experiment (Fig. 3). OsHV-1 might actively use the host's cellular mechanisms to replicate, indicating that the risk factor for OsHV-1associated mortality is increased in fast-growing oysters. In oysters, the daily growth rate regularly decreases from larvae to adult, which is consistent with a decrease of the susceptibility to OsHV-1 from larvae/spat to adults (Azéma et al., 2016; Dégremont et al., 2016; Whittington et al., 2015).

The significant interaction between families of different genetic backgrounds and size highlights the importance of genetics in this type of study, because different families exhibited contrasting mortality patterns with size (Fig. 2). Genetic background can therefore influence the outcome of such experiments, and this was demonstrated in our study. Nevertheless, identification of highly resistant and highly susceptible phenotypes with a large size range makes these contrasting families important for both selective breeding programs and research purposes. Size and age, which are usually confounding factors, are both important factors for mortality events related to OsHV-1 (Dégremont, 2011; Paul-Pont et al., 2013a; Paul-Pont et al., 2014; Peeler et al., 2012; Petton et al., 2015; Whittington et al., 2015). Overall, selective breeding programs should focus on the most resistant families, which would have to be identified at a small size. If the genetic evaluation for resistance to OsHV-1 is done too late, breeders might select families that show low mortality at large sizes, even though these families might exhibit high mortality at smaller sizes. Conversely, both susceptible families and resistant families are of great interest for research purposes, such as 
QTL identification (Sauvage et al., 2010) or transcriptomic studies (Segarra et al., 2014). At a small size, numerous families showed high mortality, whereas only a few still showed high mortality at larger sizes (Fig. 2). Thus, the families that are truly susceptible to OsHV-1 might only be identified at larger sizes.

In our experiment, only one replicate per size per family was used based on the assumption that there was an equal probability of exposure to OsHV-1 between $\mathrm{L}$ and $\mathrm{S}$ groups. This assumption was based on previous experiments at this site for which mortality related to OsHV-1 was similar among bags within families (Dégremont, 2011; Dégremont et al., 2015b). This assumption is reinforced by the height experiment, which revealed similar mortality among the bags (see below). Additionally, it is unlikely that the bags containing $\mathrm{S}$ groups were more exposed to OsHV-1 than the bags of the L group because all bags were randomly attached on the racks. Nevertheless, others studies have shown spatial and temporal variations for OsHV-1 exposure, suggesting that probability of exposure is very uneven in their sites (Paul-Pont et al., 2013b; Pernet et al., 2014). Thus, replications within size should be addressed in sites where spatial variations are known.

\subsection{Growing height investigation}

Similar to the size investigation, a significant interaction was also observed between the families and growing heights. Again, mortality was similar among the growing heights for the families displaying the extreme mortality pattern, particularly for those exhibiting very high mortality $(>95 \%)$. This result is in agreement with OsHV-1-associated mortality in triploid spat during a study conducted in 2011-2012 in Australia, in which all seed died regardless of the growing height (Paul-Pont et al., 2013a). In contrast, in our study, 9 families showed a 
significant difference in mortality among the different growing heights. Most of them displayed lower mortality for Hi and higher mortality for Lo (Figs. $5 \&$ 6). This tendency was observed in C. gigas spat in Australia (Whittington et al., 2015), as well as for adult $C$. gigas (Paul-Pont et al., 2013a; Whittington et al., 2015). Differences observed at the spat stage were explained by the use of different oyster batches, which differed in size, age and parentage (Whittington et al., 2015). Our study highlighted the importance of parentage in OsHV-1associated mortality at different growing heights. Therefore, a study investigating the growing height could reach different conclusions depending on the family tested. Highly resistant and highly susceptible families should not be used in these studies. In contrast, families showing intermediate resistance to OsHV-1 infection would better highlight the importance of this husbandry practice to limit OsHV-1 mortality. Thus, this approach could be used if farmers do not have access yet to selected oysters, although the benefit will be limited.

One hypothesis to explain the higher mortality of oysters in the Lo condition is that oysters with a longer emersion time will exhibit more growth and increased cell activity compared to oysters in the Hi condition. Consequently, OsHV-1 might have actively used the host's cellular mechanisms for its replication, and the viral load would have more quickly reached the resistance threshold of the oysters raised in the Lo condition compared to those raised in the Hi condition. As a direct consequence, at least some of the oysters in the Hi condition with genetic resistance would have had more time to limit OsHV-1 replication, and thus, the viral load would have remained below the mortality threshold. Further investigations should explore this hypothesis. Meanwhile, this finding is consistent with the size investigation, which showed that the $\mathrm{S}$ oysters had a higher susceptibility to OsHV-1 and a higher daily specific growth than the L oysters.

A second hypothesis to explain the reduced mortality in the Hi condition is that these oysters 
had reduced exposure to OsHV-1, as was reported by Paul-Pont et al. (2013a) and Whittington et al. (2015). Thus, oysters in Hi condition might have a longer span of time to limit OsHV-1 infection between successive OsHV-1 exposures, which could be enough to keep the viral load under the threshold required to cause mortality.

Another hypothesis suggests that oysters in the Hi condition are to some extent undergoing starvation compared to those in the Lo condition. It is well known that starvation is a potent stimulus of autophagy, which was recently identified as an important defense mechanism of C. gigas against OsHV-1 infection (Moreau et al., 2015). Thus, the autophagy process might have been stimulated for some oyster families maintained at the Hi condition.

\subsection{Genetic parameters of mortality}

It is likely that OsHV-1 was the main etiological agent of the mortality observed in C. gigas during the size investigation, suggesting that the mortality trait was highly linked to the resistance to OsHV-1 infection trait.

The broad and narrow sense heritabilities were similar, indicating that non-additive variance or variance due to a common environment was negligible (Table 4). Thus, both heritabilities can be regarded as equally reliable, and the combined heritability was used as the best estimate (Falconer, Mackay, 1996). The combined heritabilities for mortality in the field in November 2014 were moderate, ranging from 0.48 to 0.68 (Table 4). This result is consistent with several studies conducted to determine the resistance of $C$. gigas to OsHV-1 infection. A separate study, conducted with the same 40 full-sib families that were experimentally infected with OsHV-1 in laboratory conditions, showed the same range of heritability for the same size/age ranges (Azema et al., 2015b). Other studies focusing on mortality related to OsHV-1 
resistance in $C$. gigas also showed moderate narrow-sense heritability (Dégremont et al., 2015b), as well as moderate realized heritability after four generations of selection (Dégremont et al., 2015a).

Nonetheless, higher additive genetic variance was observed for the S group than the L group (Table 4), indicating that size has a significant effect on the estimation of heritability of OsHV-1 resistance. Azema et al. (2015a) also observed a decrease in the heritability from spat to adult, but the experimental infections were conducted at different ages.

Similar heritabilities were observed in October 2015, indicating that the influence of genetic variance was not eroded until the oysters reached market size. Our results are in agreement with those obtained for $C$. gigas on the west coast of the USA (Evans, Langdon, 2006).

\section{Conclusions}

In conclusion, our study showed that OsHV-1 played a major role in the mortality outbreak observed in spat when the temperature reached $16^{\circ} \mathrm{C}$. Our study clearly showed that smaller oysters had a higher susceptibility to OsHV-1 than larger oysters at 15 months of age. Size is a major factor that must be considered in genetic evaluations of spat resistance to mortality. This factor also discriminates the highly resistant and highly susceptible families, which is of great importance for both selective breeding programs and research purposes. Our study also showed that growing height has a limited effect on mortality related to OsHV-1 in 3 months old spat, which exhibited high mortality regardless of growing height. Meanwhile, a tendency of higher mortality in Lo (85\%) compared Hi (72\%) growing heights was observed for 9 families. Our results again highlight the importance of the germplasm used for such investigations due to the strong genetic basis for resistance to OsHV-1 in C. gigas. Finally, 
our study confirmed that the heritability of resistance to OsHV-1 in C. gigas is moderate to high and that natural selection would be expected to develop in the field.

\section{Acknowledgments}

We wish to express our gratitude to Aurélien Brun for his technical support for oyster maintenance. The oysters used in this work were produced and maintained in controlled conditions at the Ifremer hatchery in La Tremblade and at the Ifremer nursery in Bouin. We are very grateful to the hatchery and nursery teams for their assistance in oyster production.

This study was supported by Ifremer through the research activities on "Amélioration par la sélection" and by the French Ministries of Ecology and Agriculture through the research program "AESTU”. 


\section{References}

Azema, P., Travers, A., Lamy, J.-B., Dégremont, L., 2015a. Genetic parameters for OsHV-1 and Vibrio aestuarianus resistance in Crassostrea gigas: first results using controlled challenges, 107th Annual meeting of the National Shellfish Association, Monterey (CA), pp. 606.

Azema, P., Travers, M.-A., Lamy, J.-B., Degremont, L., 2015b. Genetic parameters for OsHV-1 and Vibrio aestuarianus resistance in Crassostrea gigas: first resuslts using controlled challenges. Journal of Shellfish Research. 34, 606-607.

Azema, P., Travers, M.-A., De Lorgeril, J., Tourbiez, D., Degremont, L., 2015c. Can selection for resistance to OsHV-1 infection modify susceptibility to Vibrio aestuarianus infection in Crassostrea gigas? First insights from experimental challenges using primary and successive exposures. Vet. Res. 46, 139.

Azéma, P., Travers, M.-A., Benabdelmouna, A., Dégremont, L., 2016. Single or dual experimental infections with Vibrio aestuarianus and OsHV-1 in diploid and triploid Crassostrea gigas at the spat, juvenile and adult stages. J. Invertebr. Pathol. 139, 92101.

Burge, C.A., Griffin, F.J., Friedman, C.S., 2006. Mortality and herpesvirus infections of the Pacific oyster Crassostrea gigas in Tomales Bay, California, USA. Dis. Aquat. Organ. 72, 31-43.

Burge, C.A., Judah, L.R., Conquest, L.L., Griffin, F.J., Cheney, D.P., Suhrbier, A., Vadopalas, B., Olin, P.G., Renault, T., Friedman, C.S., 2007. Summer seed mortality of the Pacific oyster, Crassostrea gigas Thunberg grown in Tomales Bay, California, USA: The influence of oyster stock, planting time, pathogens, and environmental stressors. Journal of Shellfish Research. 26, 163-172.

Clegg, T.A., Morrissey, T., Geoghegan, F., Martin, S.W., Lyons, K., Ashe, S., More, S.J., 2014. Risk factors associated with increased mortality of farmed Pacific oysters in Ireland during 2011. Prev. Vet. Med. 113, 257-267.

Dégremont, L., 2011. Evidence of herpesvirus (OsHV-1) resistance in juvenile Crassostrea gigas selected for high resistance to the summer mortality phenomenon. Aquaculture. 317, 94-98.

Dégremont, L., 2013. Size and genotype affect resistance to mortality caused by OsHV-1 in Crassostrea gigas. Aquaculture. 416-417, 129-134.

Dégremont, L., Nourry, M., Maurouard, E., 2015a. Mass selection for survival and resistance to OsHV-1 infection in Crassostrea gigas spat in field conditions: response to selection 
after four generations. Aquaculture. 446, 111-121.

Dégremont, L., Guyader, T., Tourbiez, D., Pépin, J.-F., 2013. Is horizontal transmission of the Ostreid herpesvirus OsHV-1 in Crassostrea gigas affected by unselected or selected survival status in adults to juveniles? Aquaculture. 408-409, 51-57.

Dégremont, L., Morga, B., Trancart, S., Pépin, J.F., 2016. Resistance to OsHV-1 infection in Crassostrea gigas larvae. Frontiers in Marine Science. 3.

Dégremont, L., Lamy, J.-B., Pépin, J.-F., Travers, M.-A., Renault, T., 2015b. New Insight for the Genetic Evaluation of Resistance to Ostreid Herpesvirus Infection, a Worldwide Disease, in Crassostrea gigas. Plos One. 10, e0127917.

Dégremont, L., Boudry, P., Ropert, M., Samain, J.-F., Bédier, E., Soletchnik, P., 2010. Effects of age and environment on survival of summer mortality by two selected groups of the Pacific oyster Crassostrea gigas. Aquaculture. 299, 44-50.

Domeneghetti, S., Varotto, L., Civettini, M., Rosani, U., Stauder, M., Pretto, T., Pezzati, E., Arcangeli, G., Turolla, E., Pallavicini, A., Venier, P., 2014. Mortality occurrence and pathogen detection in Crassostrea gigas and Mytilus galloprovincialis close-growing in shallow waters (Goro lagoon, Italy). Fish \& Shellfish Immunology. 41, 37-44.

EFSA, 2015. Oyster mortality. EFSA journal. 13(6), 1-59.

Evans, S., Langdon, C., 2006. Effects of genotype $x$ environment interactions on the selection of broadly adapted Pacific oysters (Crassostrea gigas). Aquaculture. 261, 522-534.

Falconer, D.S., Mackay, T.F.C., 1996. Introduction to quantitative genetics, Fourth edition ed. Addison Wesley Longman, Essex, UK.

Garcia, C., Thebault, A., Degremont, L., Arzul, I., Miossec, L., Robert, M., Chollet, B., Francois, C., Joly, J.-P., Ferrand, S., Kerdudou, N., Renault, T., 2011. Ostreid herpesvirus 1 detection and relationship with Crassostrea gigas spat mortality in France between 1998 and 2006. Vet. Res. 42, 73.

Jenkins, C., Hick, P., Gabor, M., Spiers, Z., Fell, S.A., Gu, X.N., Read, A., Go, J., Dove, M., O'Connor, W., Kirkland, P.D., Frances, J., 2013. Identification and characterisation of an ostreid herpesvirus-1 microvariant (OsHV-1 mu-var) in Crassostrea gigas (Pacific oysters) in Australia. Dis. Aquat. Organ. 105, 109-126.

Keeling, S.E., Brosnahan, C.L., Williams, R., Gias, E., Hannah, M., Bueno, R., McDonald, W.L., Johnston, C., 2014. New Zealand juvenile oyster mortality associated with ostreid herpesvirus 1-an opportunistic longitudinal study. Dis. Aquat. Organ. 109, 231-239.

Le Deuff, R.-M., Nicolas, J.-L., Renault, T., Cochennec, N., 1994. Experimental transmission of a Herpes-like virus to axenic larvae of Pacific oyster, Crassostrea gigas. Bulletin Of The European Association Of Fish Pathologists. 14, 69-72. 
Lynch, S.A., Carlsson, J., Reilly, A.O., Cotter, E., Culloty, S.C., 2012. A previously undescribed ostreid herpes virus 1 (OsHV-1) genotype detected in the pacific oyster, Crassostrea gigas, in Ireland. Parasitology. 139, 1526-1532.

Moreau, P., Moreau, K., Segarra, A., Tourbiez, D., Travers, M.-A., Rubinsztein, D.C., Renault, T., 2015. Autophagy plays an important role in protecting Pacific oysters from OsHV-1 and Vibrio aestuarianus infections. Autophagy. 11, 516-526.

Nicolas, J.-L., Comps, M., Cochennec, N., 1992. Herpes-like virus infecting Pacific oyster larvae, Crassostrea gigas. Bulletin Of The European Association Of Fish Pathologists. 12, 11-13.

Ødegård, J., Olesen, I., Gjerde, B., Klemetsdal, G., 2007. Evaluation of statistical models for genetic analysis of challenge-test data on ISA resistance in Atlantic salmon (Salmo salar): Prediction of progeny survival. Aquaculture. 266, 70-76.

Ødegård, J., Baranski, M., Gjerde, B., Gjedrem, T., 2011. Methodology for genetic evaluation of disease resistance in aquaculture species: challenges and future prospects. Aquaculture Research. 42, 103-114.

Paul-Pont, I., Dhand, N.K., Whittington, R.J., 2013a. Influence of husbandry practices on OsHV-1 associated mortality of Pacific oysters Crassostrea gigas. Aquaculture. 412413, 202-214.

Paul-Pont, I., Dhand, N.K., Whittington, R.J., 2013b. Spatial distribution of mortality in Pacific oysters Crassostrea gigas: reflection on mechanisms of OsHV-1 transmission. Dis. Aquat. Organ. 105, 127-138.

Paul-Pont, I., Evans, O., Dhand, N.K., Rubio, A., Coad, P., Whittington, R.J., 2014. Descriptive epidemiology of mass mortality due to Ostreid herpesvirus-1 (OsHV-1) in commercially farmed Pacific oysters (Crassostrea gigas) in the Hawkesbury River estuary, Australia. Aquaculture. 422-423, 146-159.

Peeler, E.J., Allan Reese, R., Cheslett, D.L., Geoghegan, F., Power, A., Thrush, M.A., 2012. Investigation of mortality in Pacific oysters associated with Ostreid herpesvirus-1 $\mu$ Var in the Republic of Ireland in 2009. Prev. Vet. Med. 105, 136-143.

Pepin, J.-F., 2013. Short Technical Report for OsHV-1 detection and quantification by Real Time Polynerase Chain Reaction using OsHV-1 DNA polymerase sequence.

Pépin, J.F., Riou, A., Renault, T., 2008. Rapid and sensitive detection of ostreid herpesvirus 1 in oyster samples by real-time PCR. J. Virol. Methods. 149, 269-276.

Pernet, F., Barret, J., Le Gall, P., Corporeau, C., Dégremont, L., Lagarde, F., Pépin, J.F., Keck, N., 2012. Mass mortalities of Pacific oysters Crassostrea gigas reflect infectious diseases and vary with farming practices in the Mediterranean Thau lagoon, France. Aquac. Environ. Interact. 2, 215-237. 
Pernet, F., Lagarde, F., Jeannée, N., Daigle, G., Barret, J., Le Gall, P., Quere, C., D’orbcastel, E.R., 2014. Spatial and Temporal Dynamics of Mass Mortalities in Oysters Is Influenced by Energetic Reserves and Food Quality. Plos One. 9, e88469.

Petton, B., Boudry, P., Alunno-Bruscia, M., Pernet, F., 2015. Factors influencing diseaseinduced mortality of Pacific oysters Crassostrea gigas. Aquac. Environ. Interact. 6, 205-222.

Roque, A., Carrasco, N., Andree, K.B., Lacuesta, B., Elandaloussi, L., Gairin, I., Rodgers, C.J., Furones, M.D., 2012. First report of OsHV-1 microvar in Pacific oyster (Crassostrea gigas) cultured in Spain. Aquaculture. 324, 303-306.

SAS, 2014. SAS software 9.4, SAS help and documentation. , SAS Institute Inc., Cary, NC, USA.

Saulnier, D., De Decker, S., Haffner, P., 2009. Real-time PCR assay for rapid detection and quantification of Vibrio aestuarianus in oyster and seawater: A useful tool for epidemiologic studies. J. Microbiol. Methods. 77, 191-197.

Sauvage, C., Boudry, P., de Koning, D.J., Haley, C.S., Heurtebise, S., Lapegue, S., 2010. QTL for resistance to summer mortality and OsHV-1 load in the Pacific oyster (Crassostrea gigas). Anim. Genet. 41, 390-399.

Schikorski, D., Renault, T., Saulnier, D., Faury, N., Moreau, P., Pepin, J.-F., 2011. Experimental infection of Pacific oyster Crassostrea gigas spat by ostreid herpesvirus 1: demonstration of oyster spat susceptibility. Vet. Res. 42, 27.

Segarra, A., Pépin, J.F., Arzul, I., Morga, B., Faury, N., Renault, T., 2010. Detection and description of a particular Ostreid herpesvirus 1 genotype associated with massive mortality outbreaks of Pacific oysters, Crassostrea gigas, in France in 2008. Virus Res. 153, 92-99.

Segarra, A., Mauduit, F., Faury, N., Trancart, S., Degremont, L., Tourbiez, D., Haffner, P., Barbosa-Solomieu, V., Pepin, J.-F., Travers, M.-A., Renault, T., 2014. Dual transcriptomics of virus-host interactions: comparing two Pacific oyster families presenting contrasted susceptibility to ostreid herpesvirus 1. Bmc Genomics. 15, 113.

Whittington, R.J., Dhand, N.K., Evans, O., Paul-Pont, I., 2015. Further observations on the influence of husbandry practices on OsHV-1 $\mu$ Var mortality in Pacific oysters Crassostrea gigas: Age, cultivation structures and growing height. Aquaculture. 438, 82-97. 


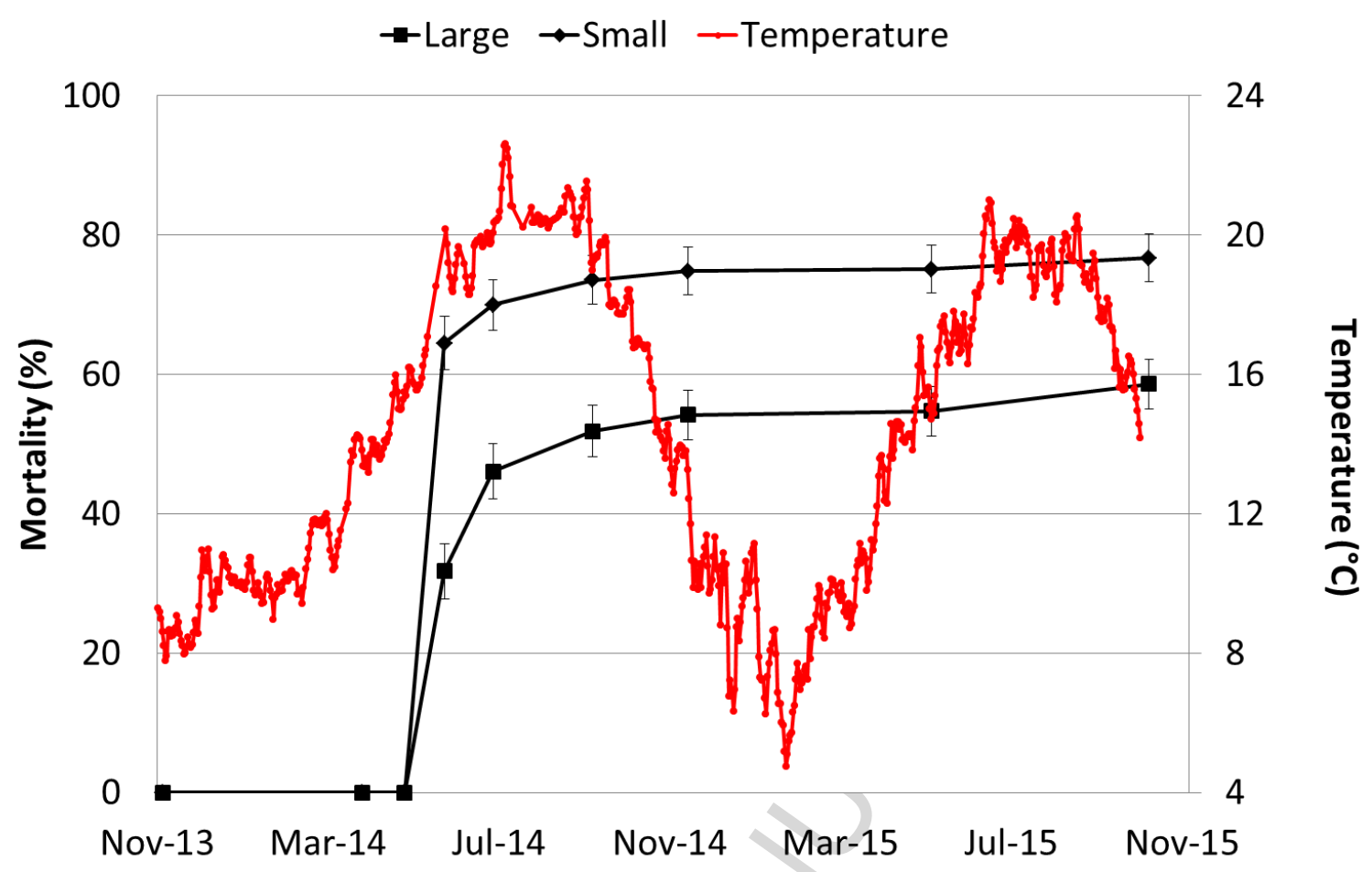

Fig. 1: Mean cumulative mortality $(\% \pm \mathrm{SE})$ of the 40 families for the large and small groups and seawater temperature $\left({ }^{\circ} \mathrm{C}\right)$ at Agnas from November 2013 to October 2015. 


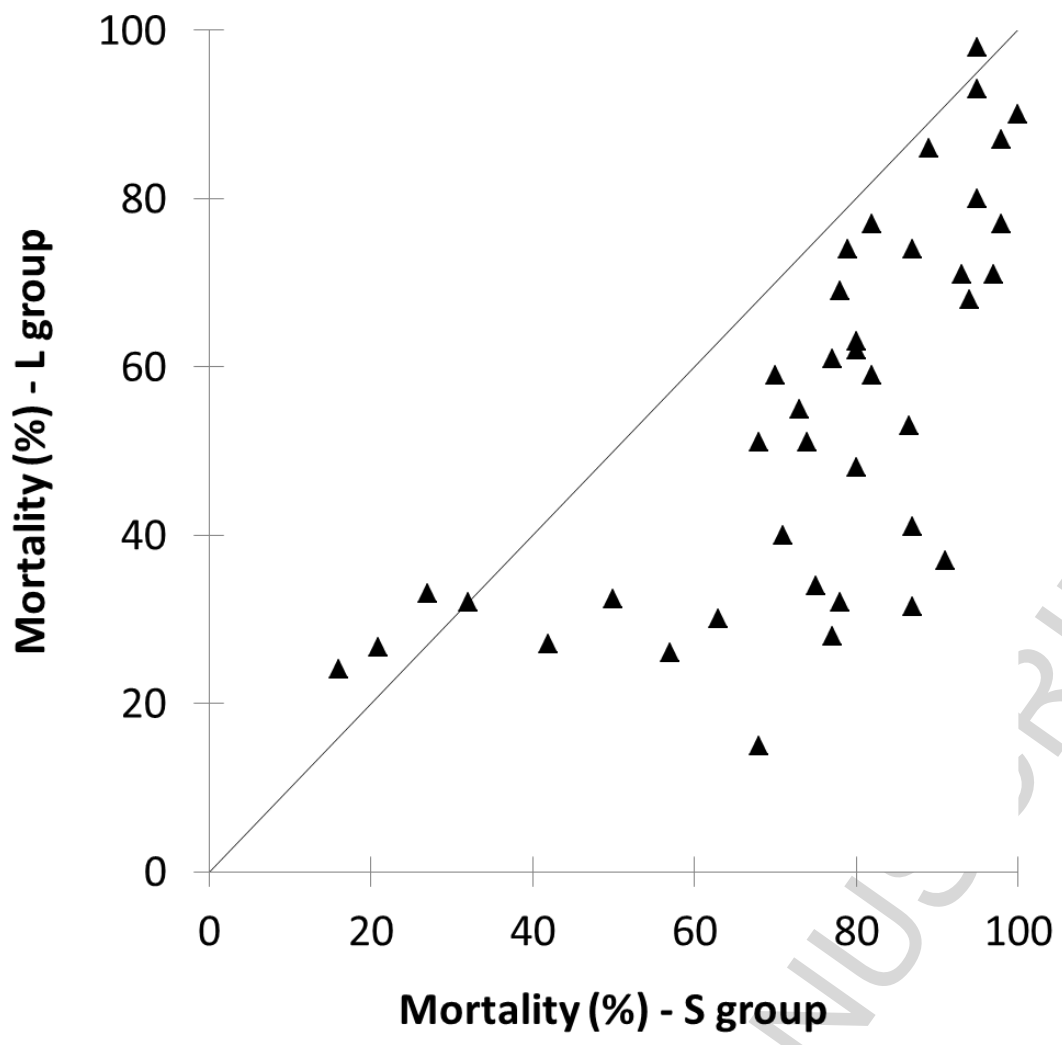

Fig. 2: Mortality (\%) for the large (L) and small (S) groups from each family at Agnas in November 2014. Each family is represented by a triangle, and a triangle located above the diagonal indicates a higher mortality for the L group, whereas a triangle located below the diagonal indicates a higher mortality for the $\mathrm{S}$ group. For example, for the left-most triangle, the S group of the family had a mortality of $17 \%$, but mortality was $22 \%$ for the L group from the same family. 
$\rightarrow$-Large $\rightarrow$ Small

-E Daily specific growth rate Large $\quad-\leftarrow$ Daily specific growth rate Small

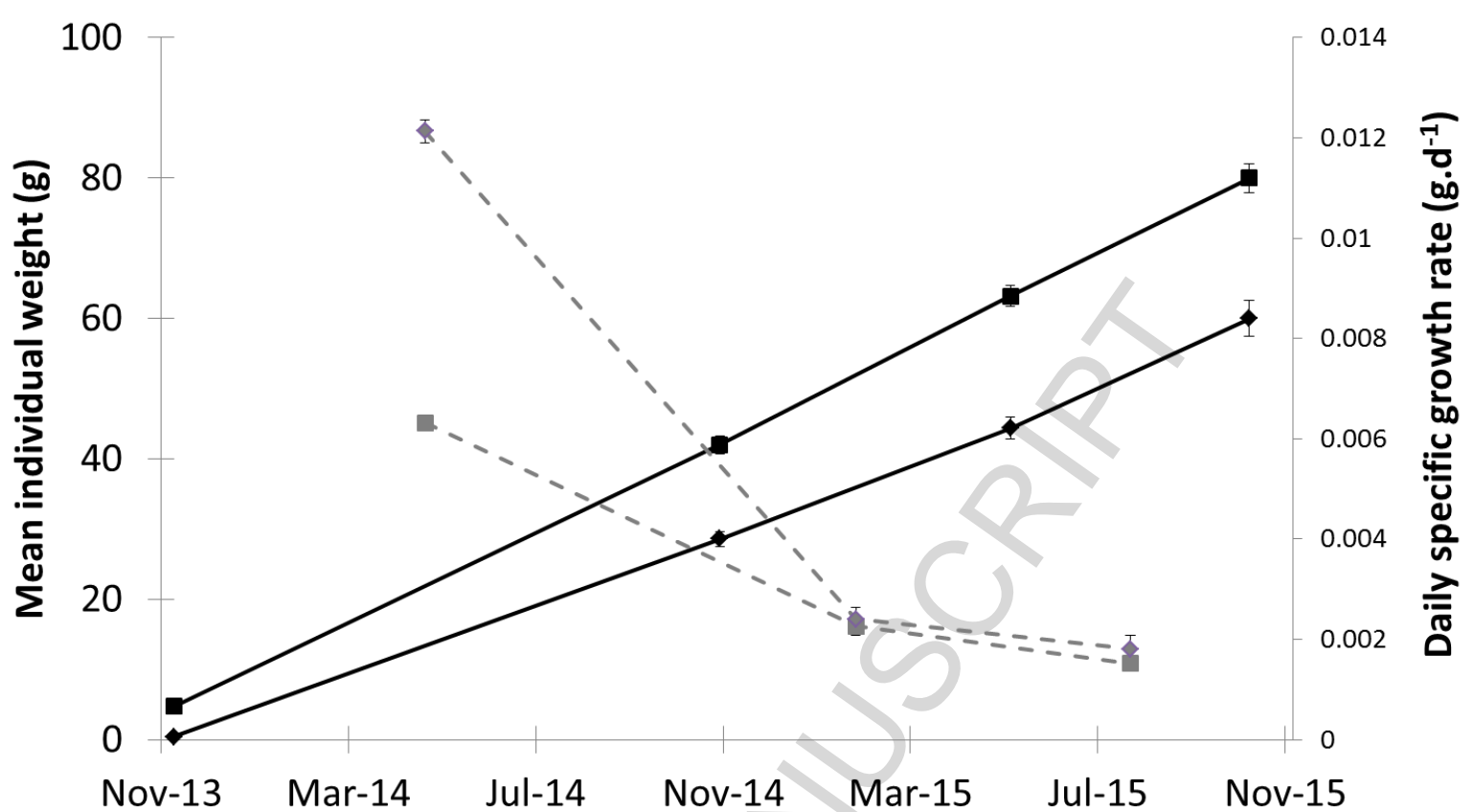

Fig. 3: Mean individual weights (g) and mean daily specific growth rate $\left(\mathrm{g.d}^{-1}\right)$ of the large and small groups ( \pm SE) at Agnas from November 2013 to October 2015. The daily specific growth rate values are ln-transformed. 


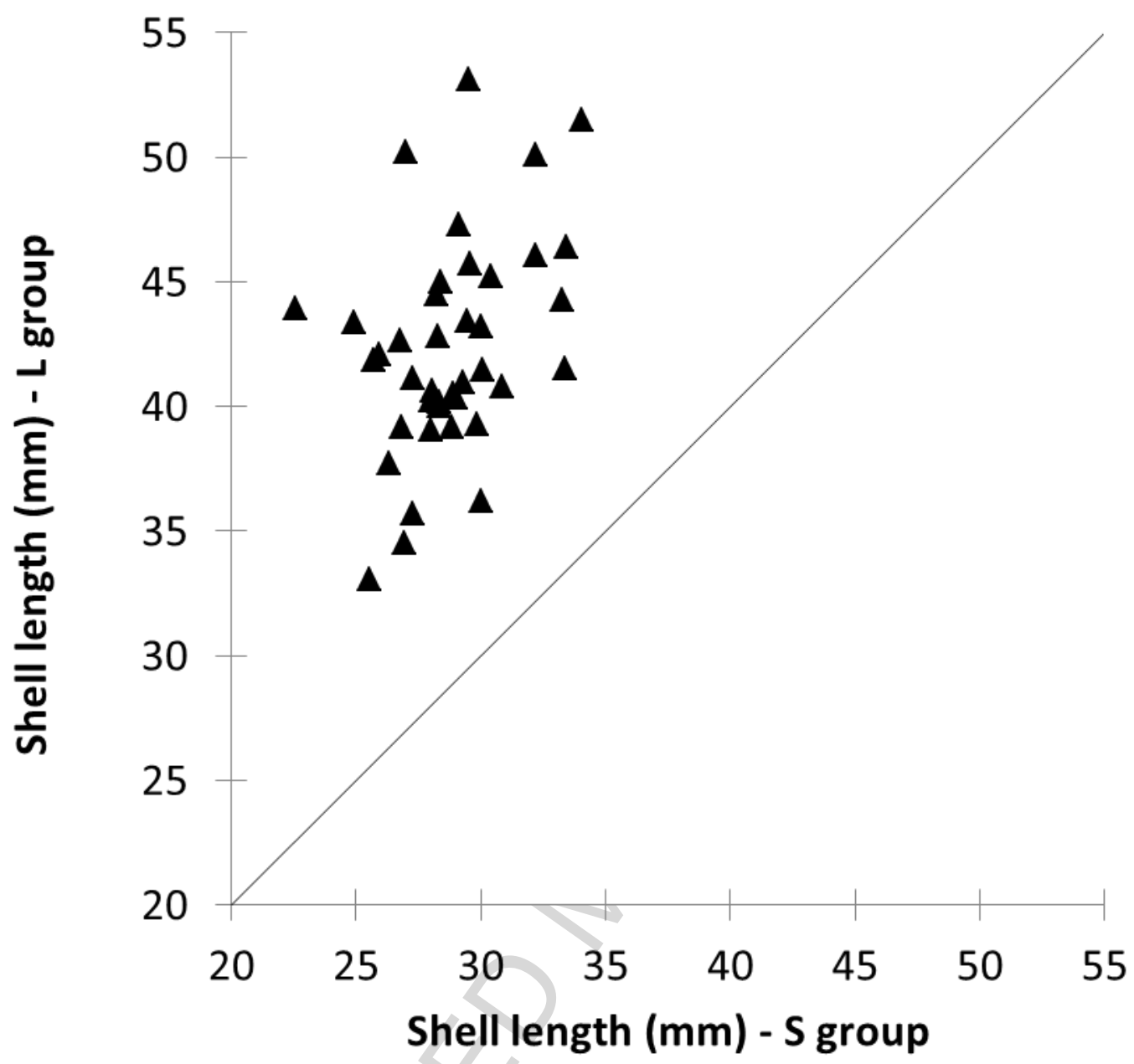

Fig. 4: Mean shell length $(\mathrm{mm})$ of dead oysters from the large (L) and small (S) groups of each family at Agnas in June 2014. Each family is represented by a triangle, and a triangle located above the diagonal indicates that the dead oysters in the L group were larger than the $\mathrm{S}$ group for a given family. For example, for the left-most triangle, the $\mathrm{S}$ group of the family had an average shell length of $22.5 \mathrm{~mm}$, but the average shell length was $44.9 \mathrm{~mm}$ for the $\mathrm{L}$ group from the same family. 


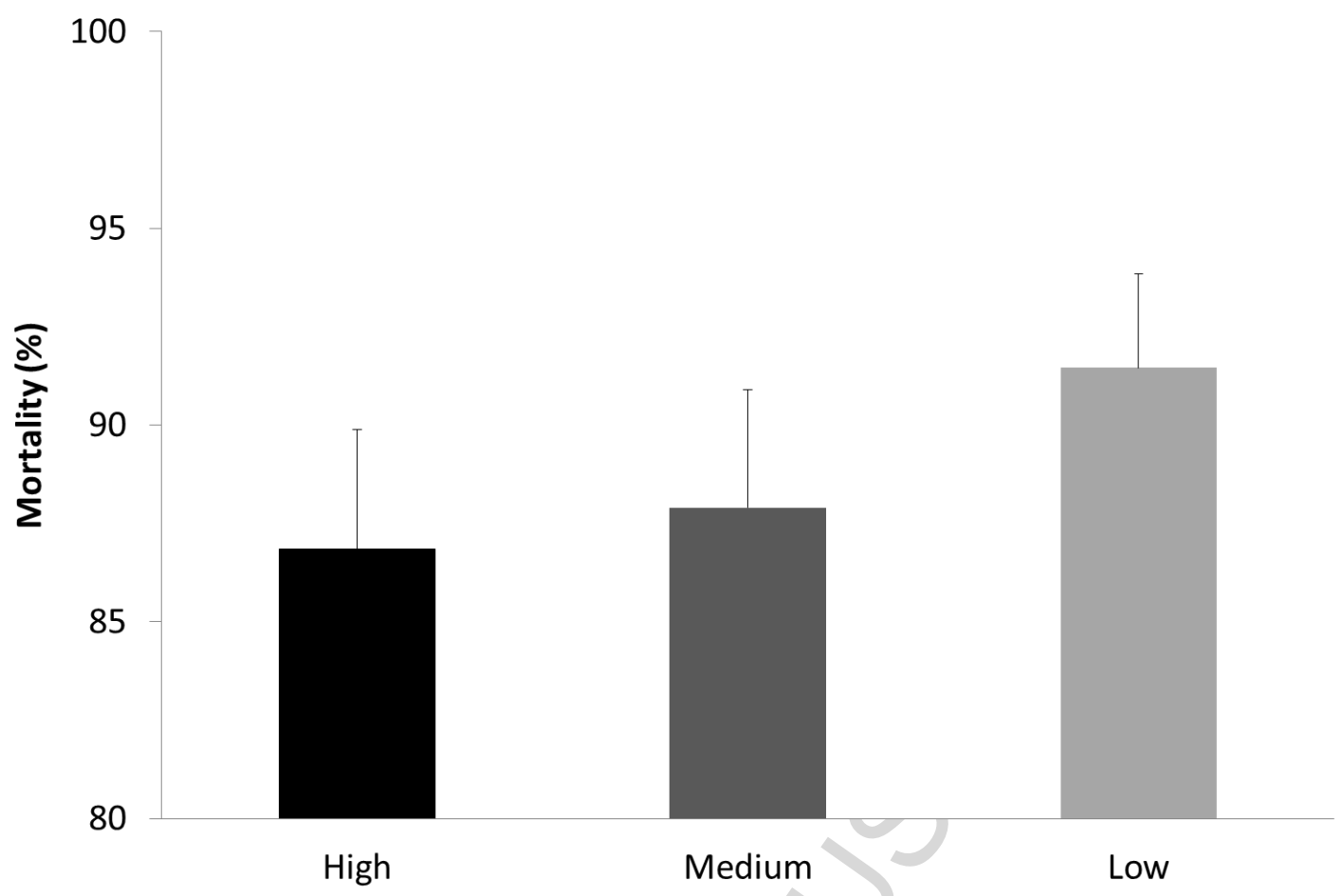

Fig. 5: Mean mortality $(\%+\mathrm{SE})$ of the 40 families tested at three growing heights six weeks after planting on September $6^{\text {th }} 2013$. 


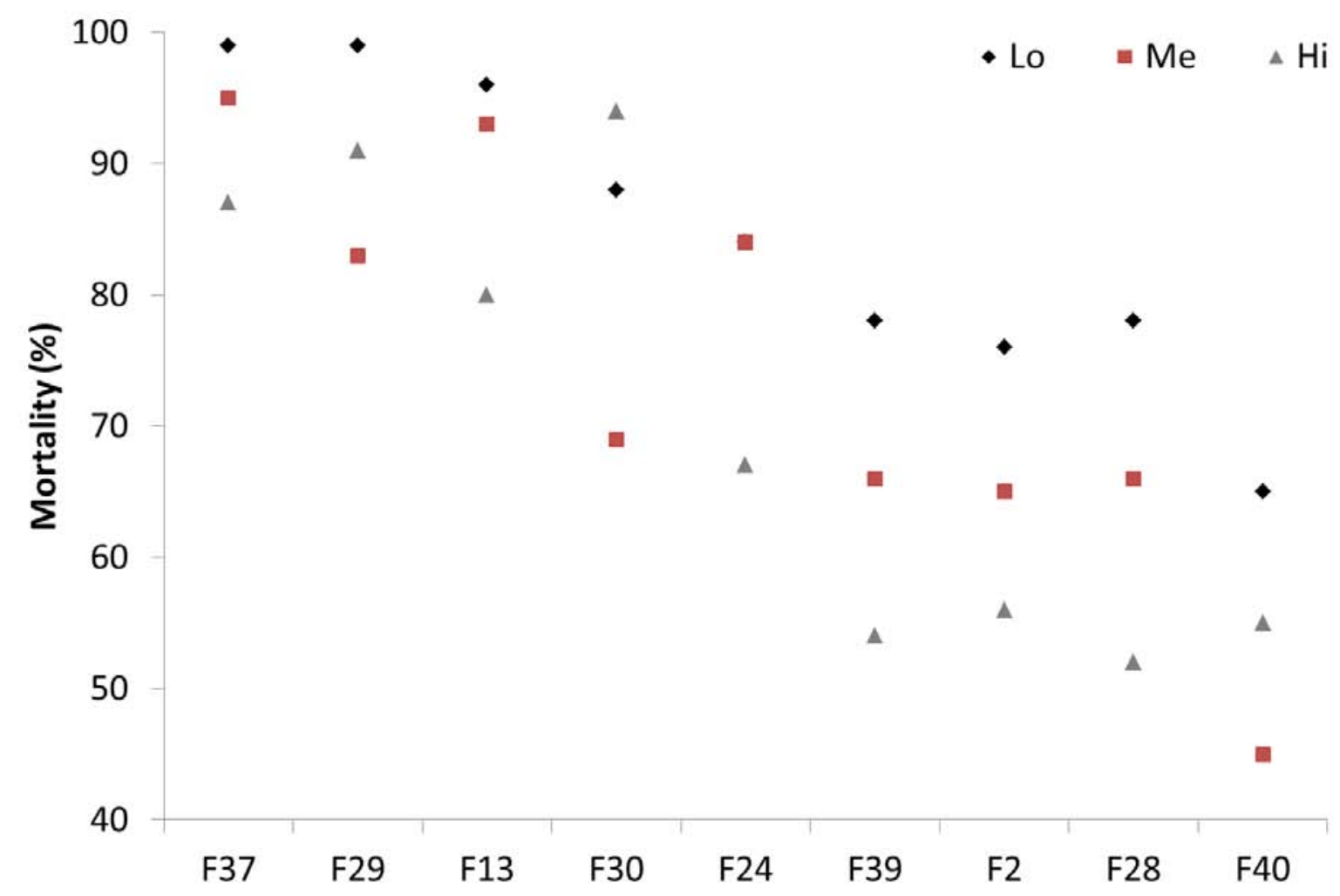

Fig. 6: Mortality (\%) of the 9 families showing a significant difference in mortality among growing conditions. 
Table 1: Logit analysis of mortality for the size investigation in November 2014

\begin{tabular}{lllllll}
\hline Source & NumDF & DenDF & Fvalue & Estimate & Standard Error & P \\
\hline Size & 1 & 39 & 61.80 & & & $<.0001$ \\
Family & & & & 1.09 & 0.30 & $<.0001^{a}$ \\
Size x Family & & & & 0.37 & 0.10 & $<.0001^{a}$ \\
\hline
\end{tabular}

${ }^{\text {a }}$ Effects are random. $\mathrm{P}$ value is from Log-likelihood ratio test by comparing the reduced and the full models. 
Table 2: Detection and quantification (DNA copies per mg of fresh oyster tissue) of OsHV-1 and Vibrio aestuarianus DNA in moribund oysters of the large and small groups from May 2014 to September 2014 during the size investigation experiment.

\begin{tabular}{|c|c|c|c|c|c|c|c|}
\hline \multirow[t]{3}{*}{ Date } & \multirow{3}{*}{$\begin{array}{l}\text { Size } \\
\text { gro } \\
\text { up }\end{array}$} & \multicolumn{3}{|c|}{ OsHV-1 } & \multicolumn{3}{|c|}{ V. aestuarianus } \\
\hline & & Positive/ana & Prevale & Quantifica & Positive/ana & Prevale & Quantifica \\
\hline & & lyzed & nce (\%) & tion & lyzed & nce (\%) & tion \\
\hline \multirow{3}{*}{$\begin{array}{l}\text { May } \\
2014\end{array}$} & Larg & $31 / 31$ & 100 & $1.910^{+8}$ & $0 / 31$ & 0 & \\
\hline & e & & & & & & \\
\hline & Sma & $30 / 30$ & 100 & $3.810^{+8}$ & $4 / 30$ & 13 & $1.510^{+6}$ \\
\hline \multirow{3}{*}{$\begin{array}{l}\text { June } \\
2014\end{array}$} & Larg & $5 / 5$ & 100 & & $1 / 5$ & 20 & $4.610^{+4}$ \\
\hline & e & & & & & & \\
\hline & Sma & $4 / 4$ & 100 & $1.510^{+8}$ & $1 / 4$ & 25 & $3.610^{+4}$ \\
\hline \multirow{3}{*}{$\begin{array}{l}\text { July } \\
2014\end{array}$} & Larg & $7 / 7$ & & $9.710^{+7}$ & $5 / 7$ & 71 & $2.010^{+7}$ \\
\hline & e & & & & & & \\
\hline & Sma & $4 / 4$ & 100 & $1.810^{+6}$ & $4 / 4$ & 100 & $5.810^{+7}$ \\
\hline Septem & Larg & $5 / 5$ & 100 & $2.210^{+7}$ & $1 / 5$ & 20 & $2.610^{+5}$ \\
\hline ber & e & & & & & & \\
\hline 2014 & Sma & $9 / 9$ & 100 & $1.510^{+7}$ & $4 / 9$ & 44 & $8.210^{+5}$ \\
\hline & II & & & & & & \\
\hline
\end{tabular}


Table 3: Logit analysis of mortality for the growing height investigation in September 2013

\begin{tabular}{lllllll}
\hline Source & NumDF & DenDF & Fvalue & Estimate & $\begin{array}{l}\text { Standard } \\
\text { Error }\end{array}$ & $P$ \\
& & & & & $<.0001$ \\
\hline Growing height & 2 & 351 & 11.14 & & 1.56 & $<.0001^{a}$ \\
Family & & & 5.64 & 0.07 & $<.0001^{a}$ \\
Family x & & & 0.19 & & \\
Growing height & & & & & \\
\hline
\end{tabular}

${ }^{a}$ Effects are random. $\mathrm{P}$ value is from Log-likelihood ratio test by comparing the reduced and the full models. 
Table 4: Variance components (additive, genetic and total for Va, Vg and Vt, respectively) and heritabilities (narrow, broad and combined for $h^{2} n, h^{2} b$ and $h^{2} m+f$, respectively) for mortality in $C$. gigas in the $\mathrm{L}$ (large) group, $\mathrm{S}$ (small) group, and both groups in November 2014 and October 2015.

\begin{tabular}{lcccccc}
\hline Variance & \multicolumn{3}{c}{ November 2014 } & \multicolumn{3}{c}{ October 2015 } \\
& Large & Small & Both & Large & Small & Both \\
\hline $\mathrm{Va}$ & $2.05 \pm 1.06$ & $3.09 \pm 1.79$ & $1.96 \pm 1.06$ & $2.01 \pm 1.05$ & $3.31 \pm 1.80$ & $2.10 \pm 1.04$ \\
$\mathrm{Vg}$ & $2.08 \pm 0.70$ & $3.76 \pm 1.38$ & $2.11 \pm 0.75$ & $1.95 \pm 0.70$ & $3.36 \pm 1.25$ & $1.90 \pm 0.65$ \\
$\mathrm{Vt}$ & $4.32 \pm 0.27$ & $5.00 \pm 0.46$ & $4.31 \pm 0.27$ & $4.28 \pm 0.26$ & $4.96 \pm 0.46$ & $4.29 \pm 0.26$ \\
& & & & & & \\
$\mathrm{~h}^{2} \mathrm{n}$ & & & & & & \\
$\mathrm{h}^{2} \mathrm{~b}$ & $0.47 \pm 0.22$ & $0.62 \pm 0.32$ & $0.45 \pm 0.23$ & $0.47 \pm 0.22$ & $0.67 \pm 0.32$ & $0.49 \pm 0.22$ \\
$\mathrm{~h}^{2} \mathrm{~m}+\mathrm{f}$ & $0.48 \pm 0.15$ & $0.75 \pm 0.26$ & $0.49 \pm 0.16$ & $0.46 \pm 0.16$ & $0.68 \pm 0.24$ & $0.44 \pm 0.14$ \\
\hline
\end{tabular}

